\title{
Studies on morphological and nutritional characteristics of different parts (Leaf, flower and pods) of Moringa oleifera (Variety : Koimtoor-1)
}

R.B. KSHIRSAGAR*, A.R. SAWATE, B.M. PATIL AND M.A. ZAKER

Department of Food Engineering, College of Food Technology, Vasantrao Naik Marathwada Krishi Vidyapeeth, PARBHANI (M.S.) INDIA

SUMMARY :

Moringa oleifera L. belongs to a family Moringaceae commonly referred to as "The Miracle Tree", 'drumstick tree' or 'horseradish tree'. This research study was aimed at investigating the morphological and nutritional characteristics of different parts of Moringa oleifera. Fresh sample of Moring a leaves, flowers and pods were collected, sorted, blanched and dried. Colour, length, width measurement of Moringa leaves and flowers while average weight and number of seeds per pod were analysed to determine morphological characteristics of Moringa oleifera. The per cent yield from different parts were also investigated. The per cent yield of blanched powders are comparatively lower then blanched samples. The blanched and dried plant samples were analysed separately for proximate composition using appropriate methods. The chemical composition of different parts of Moringa such as leaves, flower and pod for their moisture content, crude fat, crude protein, carbohydrates, crude fibre and ash were 5.4, 3.4, 28, 43, 10.2, 8.5 per cent ( for leaves); 5.7, 1.6, 24.1, 53.6, 7.5, 5.9 per cent (for flowers); 5.2, 0.5, 17, 26, 34. 1 per cent (for pods) observed, respectively.

KEY WORDS : Moringa oleifera L., Morphological, Nutritional, Yield

How to cite this paper : Kshirsagar, R.B., Sawate, A.R., Patil, B.M. and Zaker, M.A. (2016). Studies on morphological and nutritional characteristics of different parts (Leaf, flower and pods) of Moringa oleifera (Variety : Koimtoor-1). Internat. J. Proc. \& Post Harvest Technol., 7 (2) : 237-242. DOI: 10.15740/HAS/ IJPPHT/7.2/237-242. 